\title{
Tatya Loves Pomegranates
}

\author{
Maysam Abu Khreibeh
}

\begin{abstract}
This is a personal spoken word piece dedicated to moments I spent as a child with my grandmother. My grandmother is a child of the Nakba, the Palestinian "catastrophe" that exiled out over 700,000 Palestinians in 1948. In this piece, childhood observations are made of my grandmother's longing for her homeland, family and safety.The piece explores first-hand accounts of the everyday life of being a child of diaspora, such as the significance of specific foods and cultural dishes, intergenerational conflicts created in the home, and inner conflictions felt around one's faith. The piece makes space for the mundane innocence of childhood, with the striking reality of generational disruptions that stems from the displacement of one's sense of cultural rootedness, language, faith and homeland.
\end{abstract}

\section{Keywords}

Palestine, diaspora, faith, land, family, culture 
tayta ${ }^{1}$ cutting open pomegranates

summer days

in childhood

hands brittle

yet carrying oceans in each pomegranate seed

of something lost

odes to home

hymns to what could have been citrus groves

but now

she is aged

falasteen $^{2}$ on her back

$l_{a b n a n^{3}}$ under her feet

Allah on her forehead

at age 8

1948

she knew exile

she knew travel across lines

forcibly

cut

1 The transliteration for the Arabic word meaning "grandmother".

2 The transliteration for the Arabic word meaning "Palestine".

3 The transliteration for the Arabic word meaning "Lebanon". 
into

$\operatorname{dirt}$

she knew tent house,

ripped from home,

gunshot wounds,

shrapnel,

and loss of young ones,

too young to be named

she knew running

she knew 8 children

carrying them for decades

struggling to uphold

that seemed

so

forgotten

She remembered

prayer

faith

and it's inextricable

connection to place 


\section{li ilaha il Allah ${ }^{4}$}

habibti $i^{5}$ remember to eat

are you fasting?

alhamdulallah mashallah aleeki ${ }^{6}$

habibti remember to pray

habibti remember your roots

recite al fataha ${ }^{7}$ and you will heal

remember your father

he loves you

everything he does is for you

habibti remember

remember

people

in the good

and that Allah is always with you

pomegranate seeds

${ }^{4}$ The transliteration for the Arabic and Islamic phrase meaning "There is no god but God", declaring "towhid" - or the oneness of Allah.

5 The transliteration for the Arabic word meaning "my love".

6 The transliteration for the Arabic and Islamic phrase meaning "thank God" and "praise be to God, upon you".

7 The transliteration for the first chapter of the Quran, meaning "the Opening”. 
popping in my mouth

$b a b a^{8}$

silent

news

blaring

cars

rushing

tayta

p r a y ing

habibti i am so proud of you

you share the stories of our people

when i am too far from home

i remember tayta

and

when i cannot find my prayers

i remember

somebody is praying for me

8 The transliteration for the Arabic word meaning "dad". 
tayta would always make us mana'eesh ${ }^{9}$

zataar $^{10}$

khobez $^{11}$

olive oil

an ancient mixture

my brothers and i, we laugh now

but she never wanted us to go hungry

i wonder if it's because she knew the pain of a true hunger

she longed for the fruits

of a land

pulled

from

beneath

her feet

and away

from her eyes

to send one young son

across the sea

to feel the strain of a "better" life

to take the shrapnel from his feet

9 Levantine flatbread baked with a variety of toppings, often served at breakfast.

${ }^{10}$ A blend of dried oregano, marjoram, thyme, cumin and sesame seeds often used as a topping on mana'eesh.

11 The transliteration for the Arabic word meaning "bread". 
and allow him to walk

a path of safety

for family

i wonder if it's because she yearns for something that she'll never forget

zataar mana'eesh by mamas loving hands

or the way it made her late husband

smile

on early mornings

with a plate of cucumber, olives, tomatoes and onions

and always

a cup of $s h a i^{12}$

i wonder if it's because we're older now

we move in a language foreign

our tongues whip

but they are not of the honey she knows

and yet we still watch the news of a familiar life we've never lived

beside her

we never forget

those left in bleeding lands

lands far gone

from the life she remembers

12 The transliteration for the Arabic word meaning "tea". 


\section{Author Biography}

Maysam is a Muslim settler with Palestinian and Syrian roots, dwelling on the unneeded lands of Turtle Island. She is a 4th year Global Development Studies and Concurrent Education major, with specializations in First Nations, Metis and Inuit studies, and History at Queen's University. Maysam is a part of Solidarity for Palestinian Human Rights (SPHR), and the Levana Gender Advocacy Centre (LGAC), in which she is committed to solidarity projects in her communities. In her poetry, she explores questions of home, intergenerational trauma, displacement and healing through her familial and ancestral connections. 